Int. J. Morphol.,

33(2):538-543, 2015.

\title{
Dental Morphological Markers as a Proxy for Ethnicity in Robinson Crusoe Islanders
}

\author{
Marcadores Morfológicos Dentarios en la Estimación de la \\ Etnicidad Poblacional de la Isla Robinson Crusoe
}

\author{
Pía Villanueva,**,***,****; Mónica Quevedo****; Zulema de Barbieri***; Soledad Piñeiro******; \\ Carolina Herrero******; María Angélica Fernández ${ }^{* * * *}$ \& Hernán Palomino**
}

VILlANUEVA, P.; QUEVEDO, M.; DE BARBIERI, Z.; PIÑEIRO, S.; HERRERO, C.; FERNÁNDEZ, M. A. \& PALOMINO, H. Dental morphological markers as a proxy for ethnicity in Robinson Crusoe islanders. Int. J. Morphol., 33(2):538-543, 2015.

SUMMARY: Chilean Robinson Crusoe Island is a semi-isolated location with unusually high rates of both consanguinity and language disorder. The current population of 633 inhabitants is descended almost exclusively from the colonization at the end of the 19th century, as there were few preceding immigrations to the island. This study investigates the genetic composition and degree of miscegenation within the island population, using dental morphological markers. The universe of island children was studied ( $\mathrm{n}=128,3$ to 15 years of age) using clinical exams, dental cast, and identification of each individual within a previously-constructed extensive genealogy for the island. The frequencies for Carabelli's cusp (61.7\%), shovel-shaped incisor (9.4\%), and sixth cusp (2.3\%), along with the absence of seventh cusp, are consistent with a primarily Caucasian population. The estimated degree of miscegenation suggests an Amerindian component of $4.3 \%$, which is consistent with the extensive known genealogies of the founders. Characterizing the genetic profile of Robinson Crusoe Island, a location with a remarkably high prevalence of language disorder, facilitates the comparison of the genetic variants underlying this pathology with those identified in European populations.

KEY WORDS: Dental morphological markers; Carabelli's cusp; Shovel-shaped incisor; Robinson Crusoe Island.

\section{INTRODUCTION}

Existing methods for studying human variation have progressed enormously from the anthropological definitions that gave origin to the concept of race. Various levels of observation have been carried out, including isonomy, qualitative and quantitative anthropometric measures, and immunologic methods, including DNA analysis. Results from one type of analysis, however, are not always consistent with results from another (Cavalli-Sforza \& Bodmer, 1971; Rothhammer \& Llop, 2004).

Human populations live in varied conditions, some isolated for thousands of years and others with variable rates of genetic mixture among groups. Studying the effects of population mixture on genetic variation allows for a detailed evaluation of the role of the environment in diseases that have both genetic and environmental causes (Weiss, 1995).
Current Chilean populations originate from different groups, and, therefore, identifying their genetic components (gene pool) is important in epidemiologic genetic research when studying the hereditary factors underlying common diseases. Analysis of the size and shape of maxillofacial and dental structures has contributed to the study of anthropology and human evolution. Teeth have a considerable genetic component, and, under normal conditions, dental structures are the organism's most stable, changing neither in shape nor size with aging (Rothhammer \& Llop).

Dental morphological variation can be used to characterize and compare populations, as well as establish measures of biological distance similar to those established using serological or molecular markers (Palomino et al., 1977; Palomino, 1978; Rodríguez-Flórez, 2004; Bollini et

* Department of Pediatric Dentistry and Dentomaxillary Orthopedics, Faculty of Dentistry, Universidad de Chile, Santiago, Chile.

** Institute of Biomedical Sciences, Human Genetics Division, Faculty of Medicine, Universidad de Chile, Santiago, Chile.

*** Department of Speech Language and Hearing Sciences, Faculty of Medicine, Universidad de Chile, Santiago, Chile.

***** Doctoral Program of Psychology, Graduate School, Universidad de Granada, Granada, Spain.

****** Robinson Crusoe Island Health Public Centre, Juan Fernandez Archipelago, Chile.

******* Private Practice of Dentistry, Santiago, Chile. 
al., 2006; Aragón et al., 2008; Díaz et al., 2014).

Among dental phenotype is Carabelli's cusp, located on the mesiopalatine surface of the first superior molar. This is a high-frequency trait among populations of Caucasian origin (Bailit, 1975; Palomino; Villavicencio et al. 1996; Rodriguez \& Gavilanes, 2002; Rothhammer \& Llop).

Shovel-shaped incisor, a morphological variation on the palatine face of the superior incisor with variable expression, is a trait of Asian origin. It appears with high frequency among Amerindian and Eskimo, as well as Japanese and Chinese, populations (Krauss et al., 1969; Bailit; Palomino et al.).

The sixth cusp is sometimes present in the inferior molars of Asian and American Indigenous populations, and the seventh or intermedium cusp is characteristic of the inferior molars of African populations (Kraus et al.; Rothhammer \& Llop; Delgado-Burbano, 2007)

The present study was carried out in Chilean Robinson Crusoe Island, which is part of Juan Fernandez Archipelago, located 677 kilometers from central continental Chile (Fig. 1). Robinson Crusoe is a unique island, with 633 inhabitants according to the national population census (INE, 2002).

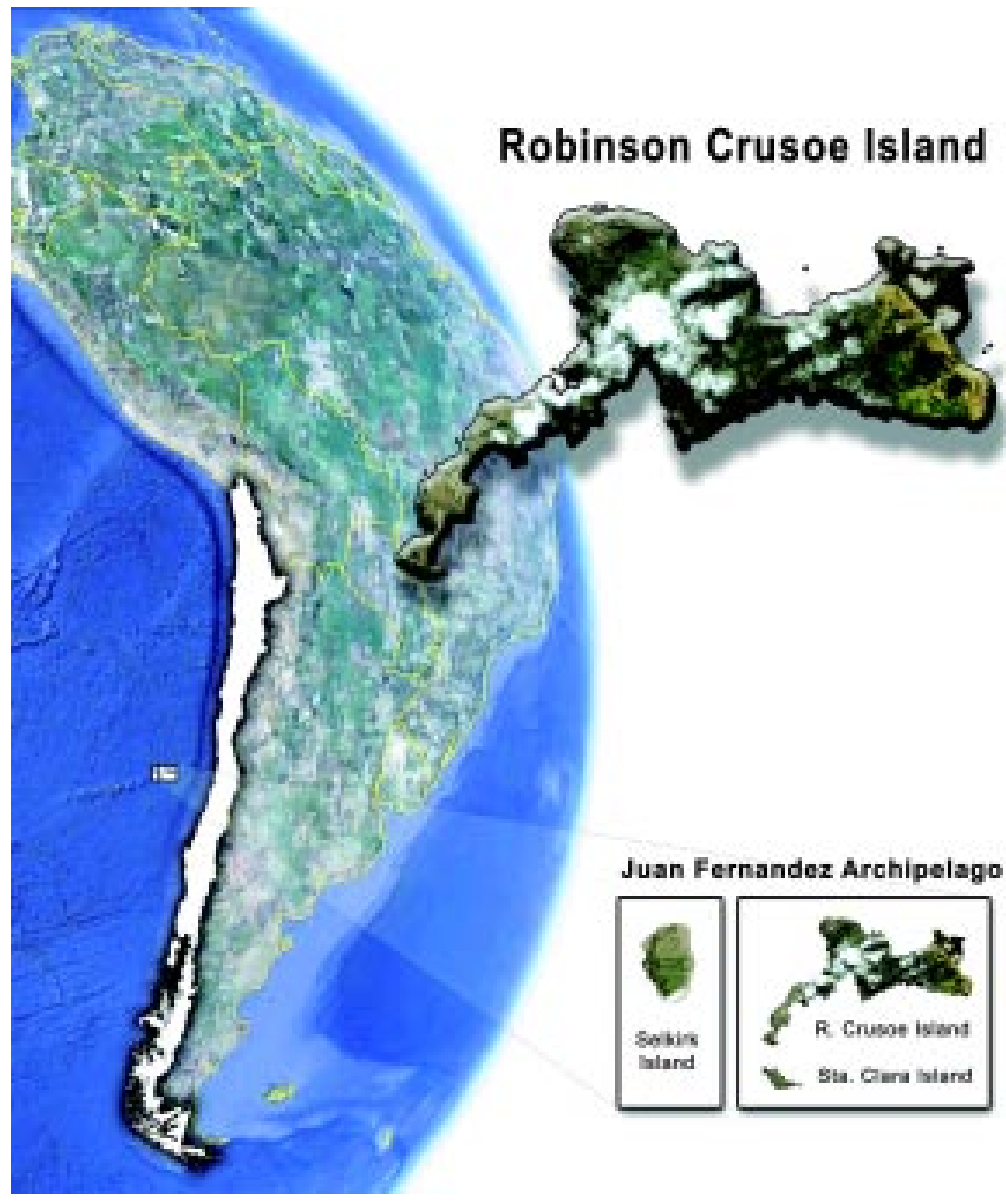

The population's genetic structure is semi-isolated, small, and of recent origin. The archipelago was discovered in 1574 and colonized in 1750; however, it was depopulated in 1850 . The most recent colonization occurred at the end of the 19th century, with 8 families led by Swiss Baron Alfred von Rodt (Vicuña Mackenna, 1883; Ruh, 1979). Of the current population of children, $77 \%$ have at least one of the colonizer's last names, consistent with the high degree of consanguinity of the island's population (Villanueva et al., 2014).

The present research group has described a high prevalence of Specific Language Impairment (SLI; SLI, MIM 602081) in this population (Villanueva $e t$ al., 2008), at a rate seven times higher than those of the continental Chilean population (De Barbieri 1999) and five times higher than those of the global population (Tomblin et al., 1997). As this language pathology has a genetic basis, it may be associated with a founder effect, that is, the genetic homogeneity that develops in isolated locations with low population variance (Cavalli-Sforza \& Bodmer; Villanueva et al., 2010, 2011).

The objective of this study is to estimate the genetic component and degree of miscegenation of the population of Robinson Crusoe Island, using dental morphological markers. The results will allow for a more detailed analysis of the genetic and environmental contribution to the risk for the disease in this population.

Fig. 1. Robinson Crusoe Island, geographic area studied $\left(33^{\circ} .37^{\prime} 56^{\prime \prime}\right.$ S.; $78^{\circ} .49^{\prime} 45^{\prime \prime}$ W). This Island belongs governmentally to the 5th region of Chile 


\section{MATERIAL AND METHOD}

The socioeconomic conditions of the island inhabitants are relatively homogenous in terms of education level and quality of life. According to data from the national population census, inhabitants are largely fishermen and belong to a middle- and lower-middle-class socioeconomic level (INE).

After signing informed consent, there were created dental casts of the superior and inferior teeth of the universe of island children aged 3 to 15 years $(n=128)$. Each child was identified within the extensive genealogy previously created.

It was recorded the following dental morphological characteristics of the teeth: shovel-shaped superior incisor, Carabelli's cusp on the superior molars, sixth and seventh cusps on the inferior molars. The evaluation criteria are described in Kraus et al.

The estimation of genetic mixture was determined based on frequency of shovel-shaped incisor and Carabelli's cusp, using the Berstein method and assuming a population of mixed Amerindian and Caucasian origin (Cavalli-Sforza \& Bodmer).

The data were compared using the Chi square method and Student t-test.

The study was approved by the Ethics Committee of the School of Medicine and undertaken as part of the UCHILE DID TNAC 01-02/01 and UCHILE DI MULT 05/

Table I. Distribution of the school- and preschool-aged population of Chilean Robinson Crusoe Island by sex and type of dentition

\begin{tabular}{lcccccc}
\hline & \multicolumn{3}{c}{ Males } & \multicolumn{2}{c}{ Females } & Total \\
\cline { 2 - 7 } & $\mathrm{n}$ & $\%$ & $\mathrm{n}$ & $\%$ & $\mathrm{n}$ & $\%$ \\
\hline Stage & 11 & 17.2 & 10 & 15.6 & 21 & 16.4 \\
1st Stage Mixed & 18 & 28.1 & 23 & 35.9 & 41 & 32.0 \\
2nd Stage Mixed & 21 & 32.8 & 13 & 20.3 & 34 & 26.6 \\
Permanent & 14 & 21.9 & 18 & 28.1 & 32 & 25.0 \\
Total & 64 & 100 & 64 & 100 & 128 & 100 \\
\hline
\end{tabular}

Table II. Dental morphological markers in the preschool- and school-aged population of Chilean Robinson Crusoe Island, by sex.

\begin{tabular}{lcccccc}
\hline & \multicolumn{2}{c}{ Males } & \multicolumn{2}{c}{ Females } & \multicolumn{2}{c}{ Total } \\
\cline { 2 - 7 } & $\mathbf{n}$ & $\mathbf{\%}$ & $\mathbf{n}$ & $\mathbf{\%}$ & $\mathbf{n}$ & $\mathbf{\%}$ \\
\hline Carabelli's cusp & 38 & 59.4 & 41 & 64.1 & 79 & 61.7 \\
Shovel-shaped incisor & 8 & 12.5 & 4 & 6.3 & 12 & 9.4 \\
Sixth cusp & 2 & 3.1 & 1 & 1.6 & 3 & 2.3 \\
Seventh cusp & 0 & 0.0 & 0 & 0.0 & 0 & 0.0
\end{tabular}

The universe of preschool- and school-aged children on Robinson Crusoe Island had an average age of 9.5 years \pm 3.2 for males and $9.5 \pm 3.1$ for females, with no significant differences of age by sex $(\mathrm{t}=0.07 ; \mathrm{p}=0.94)$. Type of dentition was mainly mixed $(58.6 \%)$, with no differences by sex $\left(\mathrm{x}_{-}=\right.$ 3.04; $\mathrm{df}=3 ; \mathrm{p}=0.52$ ) (Table I).

Of the 128 children studied, $61.7 \%$ had Carabelli's cusp, and $9.4 \%$ had shovel-shaped incisor, with no differences by sex $\left(x_{-}=1.98 ; d f=3 ; p=0.79\right)$ (Table II).

Sixth cusp was found in $2.3 \%$ of subjects with erupted inferior first molars, independent of the sex. The seventh cusp was absent in all Island children.

Table III shows the frequencies of shovel-shaped incisor and Carabelli's cusp for the Island population in comparison with estimated frequencies for larger racial groups and various continental Chilean populations. Shovelshaped incisors were found at significantly lower frequency in comparison to the other populations $\left(\mathrm{x}_{-}=69.17 ; \mathrm{p}=\right.$ 0.0001), and Carabelli's cusp is common among Islanders. Carabelli's cusp is found at high frequency in mainly Caucasian populations and low frequency in Asian and Indigenous populations. The frequency found for Island children is significantly higher $\left(\mathrm{x}_{-}=201.5 ; \mathrm{p}=\right.$ 0.0001 ) than for children attending public school in Santiago and southern Chile. Students atprivate schools, especially in southern Chile, show values closer to those of the children of the island (Palomino et al.).

The ethnic composition of the populated was calculated using the Bernstein method for markers Carabelli's cusp and shovel-shaped incisor. The degree of miscegenation estimated, which represents the average of the two markers, indicates that the Amerindian component of the population of Robinson Crusoe Island was $4.34 \%$. This value is compared with those obtained for the continental Chilean population and larger Caucasian and Amerindian racial groups in Table III. 
Table III. Frequency of dental morphological characteristics in the Chilean Robinson Crusoe Island, in continental Chile, and in larger racial groups.

\begin{tabular}{lccc}
\hline & $\begin{array}{c}\text { Carabelli's } \\
\text { cusp }\end{array}$ & $\begin{array}{c}\text { Shovel-shaped } \\
\text { incisor }\end{array}$ & $\begin{array}{c}\text { GENETIC } \\
\text { MIX }\end{array}$ \\
\hline Populations & $\%$ & $\%$ & $\%$ \\
Robinson Crusoe Island $^{1}$ & $\mathbf{6 1 . 7}$ & $\mathbf{9 . 4}$ & $\mathbf{4 . 3}$ \\
Caucasian 2 $^{1}$ & 59.5 & 12.6 & --- \\
Amerindian $^{2}$ & 7.2 & 88.6 & --- \\
Santiago public school $^{2}$ & 15.5 & 41.7 & 70.7 \\
Santiago private school 2 $^{\text {Southern Chile public school }}{ }^{3}$ & 24.7 & 19.5 & 37.8 \\
Southern Chile Private school $^{3}$ & 23.7 & 62.4 & 66.6 \\
\hline
\end{tabular}

$1=$ Data obtained in the present study.

2= Data published by Palomino et al. Morfología Dentaria en la Evaluación de la Etnicidad Poblacional. Odontología Chilena 43, 91-94, 1995.

3= Data published by Rothhammer \& Llop, Poblaciones chilenas. Cuatro décadas de investigaciones bioantropológicas. Editorial Universitaria, Santiago, pp. 115-128, 2004

\section{DISCUSSION}

It was described a high prevalence of Specific Language Impairment in children on Robinson Crusoe Island, at rates well above those reported for populations in Santiago de Chile or Europe (Villanueva et al., 2008). This language disorder has been described as highly heritable, complex, and multifactorial (Newbury et al., 2010; Villanueva et al., 2011). Therefore, identifying the genetic components of this interesting population (gene pool) allows for a more detailed evaluation of the role of genetic and environmental contributions in this developmental disorder.

Current Chilean populations are descended from different origins and, therefore, their population structure and degree of genetic mixture cannot be assumed. It is known that the country's population is descended primarily from the mix of Amerindian inhabitants and European settlers that colonized the country after its discovery and conquest (Rothhammer \& Llop). It is also known that the Amerindian populations were genetically homogeneous but that the proportion of European or African genetic contribution varies within the population (Salzano \& Callegari-Jacques, 1988). In Chile, the impact of African genes is quite low (Rothhammer \& Llop).

Chilean Robinson Crusoe Island is highly endogamic, with a recent and known origin, with little prior immigration. The names of $77 \%$ of current children remain the same as those of the founding families (Villanueva et al., 2008). The families that colonized the island originate from a rural zone in the center of Chile, descended primarily from Spanish settlers with a relatively low indigenous component. Few of the settlers had other European backgrounds including German, French, and Swiss.
There are various methods for establishing the ethnic composition of a population, each of which has been demonstrated to be useful and to provide equivalent results.

Dental markers have been widely used because of their stable morphology over the lifespan. Studies of intraand interpopulation dental morphological variability in groups with varying levels of indigenous American genetic contribution have concluded that philogenetic comparisons based on dental morphology are a useful indicator of biological distance (Palomino et al.).

In the Robinson Crusoe Islanders, it was analyzed four markers that are clearly different among racial groups. Out results show that the frequency of indigenous genes in the population is low (4\%) and that there is no presence of African genes, which is consistent with historical and demographic data regarding the origin of this population (Vicuña Mackenna; Arana, 2010).

Furthermore, studies of schoolchildren in Santiago and Southern Chile show that dental morphology is a good phenotypic marker for estimating the degree of mixture within the population, with results equivalent to those obtained using serological markers in the same individuals. Populations of private and public school students in Santiago evaluated from a socioeconomic and ethnic perspective showed lower levels of Amerindian component than their public school counterparts (Valenzuela et al., 1987). In the rural zone of Southern Chile, especially in the Lake District, there has been a recent immigration of individuals from Germany resulting in relatively closed groups with respect to the surrounding resident population, and especially 
exclusive of the numerous indigenous settlements. Currently, the public schools in the zone are attended by both indigenous and non-indigenous students from the mixed Chilean population, while the private schools of German origin are attended mainly by students from the colonizing German families. Studies have shown a similar pattern for school populations in Santiago (Rothhammer \& Llop).

The high frequency of Carabelli's cusp and low frequency of shovel-shaped incisor described in the present work allows us to conclude that the population of Robinson Crusoe Island has remained semi-isolated, with scarce genetic variability. The population has maintained the characteristics of the founding families originating mainly from Europe. The absence of the seventh cusp rules out the existence of African genes.

Significantly, the frequency of shovel-shaped incisor on the Island is similar to that described for Caucasians and lower than that described for indigenous South American populations, while Carabelli's cusp is more common than in urban continental Chilean populations. Populations influenced by racial mixing and less isolation generally show higher frequencies of traits of Caucasoid origin and decreased frequencies of Amerindian traits (Palomino et al.; Aragón et al.).

The frequency of Specific Language Impairment in the island (35\%) (Villanueva et al., 2008) is higher than in English spoken children (Tomblin et al.) or continental Chile (De Barbieri et al., 1999), where rates are below $10 \%$. This island population with a low frequency of indigenous genes can be considered to be mainly European in origin. Therefore, it would be useful to compare the genetic profiles of SLI cases reported in Europe with those in Robinson Crusoe Island.

In fact, four genes associated with spoken language disorder have been identified in European populations (for more detail see Newbury et al.).
In the population of Robinson Crusoe, a marker has been identified, along with five zones highly associated with the pathology on other chromosomes (Villanueva et al., 2010, 2011). Among these, a zone in chromosome 7 coincides with the location of genes identified as an area of susceptibility for SLI, autism, and vocabulary and grammar disorders. Furthermore, it coincides with the location of the gene FOXP2 recognized as an area of susceptibility for speech and language disorders over a decade ago, and described as a biological modulator of the evolution and development of language in the human species (Konopka et al., 2009).

In conclusion, this study confirmed a scarce indigenous genetic contribution to the semi-isolated Chilean population of Robinson Crusoe Island, according to dental morphological markers. This is the first step in describing the genetic profile of this population, in which a high prevalence of language disorder is reported. This characterization paves the way for comparisons of the genetic variants underlying the language pathologies described in European populations with findings for this Chilean island population.

\section{ACKNOWLEDGEMENTS}

The authors are extremely grateful to the inhabitants of Robinson Crusoe Island who have agreed to participate in this study. We would also like to thank to the Mayor of the Ilustre Municipalidad de Juan Fernandez, for his infinite assistance in the development of this research.

FUNDING. The characterization of the Robinson Crusoe population was funded by two grants of Vicerrectoría de Investigación, Universidad de Chile [grant number UCHILE DID TNAC 01-02/01], [grant number UCHILE DI MULT 05-05/02].

VILlANUEVA, P.; QUEVEdo, M.; DE BARBIERI, Z.; PIÑEIRO, S.; HERRERO, C.; FERNÁNDEZ, M. A. \& PALOMINO, H. Marcadores morfológicos dentarios en la estimación de la etnicidad poblacional de la Isla Robinson Crusoe. Int. J. Morphol., 33(2):538-543, 2015.

RESUMEN: La isla chilena Robinson Crusoe es un semiaislado geográfico de alta consanguinidad. Su población actual de 633 habitantes proviene de la última colonización ocurrida a finales del siglo XIX y pocas migraciones posteriores, en quienes recientemente se ha descrito una alta incidencia de trastorno de lenguaje. Este estudio estimó el componente genético y grado de miscegenación de la población isleña usando marcadores morfológicos dentarios. Se estudió al universo de niños isleños ( $\mathrm{n}=128,3$ a 15 años de edad) con exámenes clínicos, modelos dentales y ubicación de cada individuo en genealogías extensas confeccionadas previamente. La frecuencia de Tubérculo de Carabelli fue 61,7\%, Diente en Pala 9,4\%, tubérculo sexto 2,3\% y ausencia del rasgo tubérculo séptimo, lo que concuerda con una población eminentemente caucásica. El grado de miscegenación estima que el componente amerindio de esta población es de 4,3\%, que también se evidencia al analizar las genealogías extensas originadas por los colonizadores. La descripción del perfil genético de esta población, donde se han reportado altas prevalencias de trastorno de lenguaje, permitirá comparar con las variantes genéticas subyacentes a esta patología descritas para poblaciones europeas.

PALABRAS CLAVES: Marcadores morfológicos dentarios; Tubérculo de Carabelli; Incisivo en forma de pala; Isla Robinson Crusoe. 


\section{REFERENCES}

Aragón, N.; Bastidas, C.; Bedón, L.K.; Duque, P.; Sánchez, M.; Rivera, S.; Triana, F.; Bedoya, N. \& Moreno, F. Rasgos morfológicos dentales coronales en dentición temporal y permanente: Distancia biológica entre tres grupos indígenas del Amazonas Colombiano. Rev. Odontol. Mex., 12(1):13-28, 2008.

Arana, P. M. La isla de Robinson Crusoe. Valparaiso, Ediciones Universitarias de Valparaiso, Pontificia Universidad Católica de Valparaíso, 2010.

Bailit, H. L. Dental variation among populations. An anthropologic view. Dent. Clin. North Am., 19(1):125-39, 1975.

Bollini, G. A.; Rodríguez-Flórez, C. D.; Colantonio, S. E.; Méndez, M. G. Morfología dental de una serie prehistórica de Araucanos provenientes de la Patagonia Argentina y su relación biológica con otras poblaciones prehistóricas argentinas y del mundo. Int. J. Morphol., 24(4):705-12, 2006.

Cavalli-Sforza, L. L. \& Bodmer, W. F. The genetics of Human Populations. San Francisco, W. H. Freeman \& Co. Dover Publications, 1971.

De Barbieri, Z.; Maggiolo, M. \& Alfaro, S. Trastornos de la comunicación oral en niños que asisten a control de salud en un consultorio de atención primaria. Rev. Chil. Pediatr., 70(1):36-40, 1999.

Delgado-Burbano, M. E. Population affinities of African Colombians to SubSaharan Africans based on dental morphology. Homo, 58(4):329-56, 2007.

Díaz, E.; García, L.; Hernández, M.; Palacio, L.; Ruiz, D.; Velandia, N.; Villavicencio, J. \& Moreno, F. Frequency and variability of dental morphology in deciduous and permanent dentition of a Nasa indigenous group in the municipality of Morales, Cauca, Colombia. Colomb. Med. (Cali), 45(1):15-24, 2014.

Instituto Nacional de Estadísticas (INE). Chile: Censo Nacional de Población y Vivienda 2002. Santiago, Gobierno de Chile, 2002. Disponible en: http://espino.ine.cl/cgibin/RpWebEngine.exe/ $\mathrm{P}$ orta 1 A c $\mathrm{t}$ i o $\mathrm{n}$ ? \& $\mathrm{M}$ O D E = M A I N \& B A S $\mathrm{E}=\mathrm{CPCHL} 2 \mathrm{KCOM} \& \mathrm{MAIN}=$ WebServerMain.inl

Konopka, G.; Bomar, J. M.; Winden, K.; Coppola, G.; Jonsson, Z. O.; Gao, F.; Peng, S.; Preuss, T. M.; Wohlschlegel, J. A. \& Geschwind, D. H. Human-specific transcriptional regulation of CNS development genes by FOXP2. Nature, 462(7270):213-7, 2009.

Kraus, B. S.; Jordan, R. E. \& Abrams, L. Dental anatomy and occlusion. Baltimore, Williams \& Wilkins Company, 1969.

Newbury, D. F.; Fisher, S. E. \& Monaco, A. P. Recent advances in the genetics of language impairment. Genome Med., 2(1):6, 2010.

Palomino, H.; Chakraborty, R. \& Rothhammer, F. Dental morphology and population diversity. Hum. Biol., 49(1):61-70, 1977.

Palomino, H. The Aymara of western Bolivia: III. Occlusion, pathology, and characteristics of the dentition. J. Dent. Res., 57(3):459-67, 1978.

Rodríguez, C. D. \& Gavilanes, D. M. Morfología dental de la población enterrada en el cementerio prehispánico de Obando al norte de Valle del Cauca entre los siglos VIII y XIII d.C. Rev. Fed. Odontol. Colomb., 63:100-14, 2002.
Rodríguez-Flórez, C. D. La antropología dental y su importancia en el estudio de los grupos humanos prehispánicos. Rev. Antropol. Exp., 4:1-7, 2004.

Rothhammer, R. \& Llop, E. Poblaciones chilenas: Cuatro décadas de investigaciones bioantropológicas. Santiago, Editorial Universitaria, 2004.

Ruh, M. Alfredo Von Rodt, Subdelegado de Juan Fernández. Santiago, Depto. de Ciencias Antropológicas y Arqueológicas Universidad de Chile, 1979.

Salzano, F. M. \& Callegari-Jacques, S. M. South American Indians: A case study in evolution. Oxford, Clarendon Press, 1988.

Tomblin, J. B.; Records, N. L.; Buckwalter, P.; Zhang, X.; Smith, E. \& O'Brien, M. Prevalence of specific language impairment in kindergarten children. J. Speech Lang. Hear. Res., 40(6):1245-60, 1997.

Valenzuela, C. Y.; Acuña, M. P. \& Harb, Z. Gradientes sociogenéticos en la población chilena. Rev. Med. Chil., 115(4):295-9, 1987.

Vicuña Mackenna, B. Juan Fernández. Historia verdadera de la isla de Robinson Crusoe. Tomos I y II. Valparaíso, Ediciones Universitarias de Valparaíso, 1883.

Villanueva, P.; de Barbieri, Z.; Palomino, H. M. \& Palomino, H. Alta prevalencia de trastorno específico de lenguaje en isla Robinson Crusoe. Un probable efecto fundador. Rev. Med. Chil., 136(2):186-92, 2008.

Villanueva, P.; Jara, L. \& Palomino, H. Association of D16S515 microsatellite with specific language impairment on Robinson Crusoe Island, an isolated Chilean population: a possible key to understanding language development. Hum. Biol., 82(4):395-408, 2010.

Villanueva, P.; Newbury, D. F.; Jara, L.; De Barbieri, Z.; Mira, G.; Palomino, H. M.; Fernández, M.A.; Cazier, J. B.; Mónaco, A. \& Palomino, H. Genome-wide analysis of genetic susceptibility to language impairment in an isolated Chilean population. Eur. J. Hum. Genet., 19(6):687-95, 2011.

Villanueva, P.; Fernández, M. A.; De Barbieri, Z. \& Palomino, H. Consanguinity on Robinson Crusoe Island, an isolated Chilean population. J. Biosoc. Sci., 46(4):546-55, 2014.

Villavicencio, J. A.; Fernández, M. A. \& Magaña, L. Evolución de las Piezas Dentarias. En: Villavicencio, J. A.; Fernández, M. A. \& Magaña, L. (Eds.). Ortopedia Dentofacial: Una Visión Multidisciplinaría. Caracas, Actualidades Médico Odontológicas Latinoamérica, 1996. pp.77-87.

Weiss, K. M. Genetic variation and human disease: Principles and evolutionary approaches. Cambridge, Cambridge University Press, 1995.

\section{Correspondence to:}

Pia Villanueva

Sergio Livingstone Pohlhammer 943

Independencia

ZC: 8380492

Santiago

CHILE

Email: piavilla@u.uchile.cl
Received: 30-11-2014

Accepted: 19-03-2015 